\title{
ANALYSIS OF STUDENTS MENTAL MODELS THROUGH POE (PREDICT OBSERVE EXPLAIN) METHOD IN SALT HYDROLISIS TOPIC
}

\author{
Kiswandari $^{{ }^{*}}$ and Achmad Ridwan ${ }^{1}$ \\ ${ }^{1}$ Chemistry Education, Postgraduate Program, Faculty of Mathematics and Natural Sciences, \\ Jakarta State University, Jl. Rawamangun Muka, RT.11 / RW.14, Rawamangun, Kec. Pulo \\ Gadung, Kota Jakarta Timur, Daerah Khusus Ibukota Jakarta 13220, Indonesia \\ *E-mail: wanda.kiswandari13@gmail.com
}

Received: 29 October 2019; accepted: 31 March 2020; Published: 30 June 2020

\begin{abstract}
This study aimed to analyze students mental models in salt hydrolysis topic using POE method (Predict Observe Explain) to determine students understanding of salt hydrolysis topic. The research method used descriptive qualitative approach. Data collection used diagnostic tests of mental models, observation, reflective journals and semi-structured interviews on samples of respondents of students class XI. The result showed that 3.88\% of respondents had a Specific Misconceptions (SM) mental model, 7.9\% Partially Correct (PC) and 88.146\% Scientifically Correct (SC). It can be concluded that the majority of respondents have scientifically correct mental models and show themes which appeared at each macroscopic, symbolic and microscopic.
\end{abstract}

Keywords: mental model, $\mathrm{POE}$, salt hydrolisis

DOI: https://doi.org/10.15575/jtk.v5i1.5681

\section{INTRODUCTION}

Chemistry is an important branch of science. Material structure and changes experienced by material are studied in chemistry (Murezhawati et al., 2016). Three domains of chemistry were represented as a triangle of chemical. Learning chemistry is always associated with three levels of chemistry, namely macroscopic, microscopic and symbolic (Johnstone, 1991; Johnstone,1993).

The results of Treagust and Chandrasegaran's (2007) study showed that the reason why students have difficulty to understand chemistry is because students are not able to concretize abstract levels of structure and processes at the submicroscopic level, students are unable to relate to other representative levels of chemistry. According to Sari and Seprianto (2018) students' difficulties in transforming the three levels of chemical phenomena are due to the lack of training of students in learning with representations of submicroscopic levels, where chemistry learning takes place still tends to separate the three levels of the chemical phenomenon. According to Treagust and Chandrasegaran (2007), chemistry is a difficult material at the high school level. 

Hydrolisis Topic

Based on the background, the researcher aimed to see the mental model of students that were formed from the understanding gained from the chemistry learning material. The mental model that emerges is then analyzed to determine the extent whether the students understand or not about the Salt Hydrolysis topic. Mental models can be described as a construction that cannot be observed, personal cognitive representation, mental images, mental processes, and a personal mental or internal representation of an idea or concept (Chermack et al., 2012). The correct mental model of chemical material will be stored in memory (Halim et al., 2013). Many methods are carried out by various researchers in exploring mental models, including through the provision of combined questions, both reasoned multiple choices, descriptions, and interviews and classroom observations (Buckley \& Boulter, 2000; Harrison \& Treagust 2000).

The POE technique probes for learners' understanding by requiring them to first predict an outcome of some events and to provide reasons. After the event is demonstrated, they then describe what they saw, and finally reconcile any conflict between prediction and observation and justify their explanation. White and Gunstone (1992) indicated that a prediction is more likely to require the respondents to use their knowledge to reason an answer rather than to reproduce textbook knowledge without thinking. POE allows researchers to investigate not only the respondents' explanations based on his/her mental model, but also what conditions of the event that he/she believes need to be considered. The POE technique is very suitable to be applied on hydrolysis topic, because this topic contains concepts that require direct observation, so that students can observe the symptoms that occur, make guesses based on initial knowledge, experience and literature, explain the results based on direct observation data, and draw conclusions based on observations made so that they can be understood and durable in memory.

The POE -Predict-Observe-Explain- model is very suitable to be used on salt hydrolysis topic since it contains concepts that require direct observation. Furthermore students can observe the occurred symptoms, guess something based on initial knowledge experience and literature, explain results based on direct observation data and draw the conclusion based on observation made. Consequently, they can understand and memorize all the materials permanently. The advantage of POE learning is to stimulate students to be creative especially in submitting predictions. Experiments were conducted to test students predictions, it showed that students were more interested in the learning process because they not only can listen but also observe events that occurred. Additionally, they will have the opportunity to compare the theory and reality directly and are able to believe in the truth of learning material; thus students will be more able to believe in the truth of learning material (Murezhawati \& Melati 2016). At the prediction stage, students were asked to write down their predictions regarding something will happen on Students Worksheet. The teacher asked students about what they think, what they see and the reason. At the observation stage, students conducted experiments (Practicum) relating to the problems that have been decided by the teacher. The students then observed the results of the experiment to test the predictions of the truth that the students have made before. At the explanantion stage, students compared the results of observations with the results of predictions 

Hydrolisis Topic

then they gave an explanation of why this can be happened (Murezhawati \& Melati 2016).

One of chemical materials that is considered difficult is salt hydrolysis topic. In this material we discuss the reaction of ionization of salt dissolved in water. This reaction is certainly not visible to the students. The material requires student understanding in macroscopic, microscopic and symbolic forms. In his study Murezhawati and Melati (2016) stated that in hydrolysis topic, students did not understand the concept of hydrolysis and lacked mastery in calculating the $\mathrm{pH}$ of salt solutions, lack of understanding of the concept of hydrolysis in question, students could not describe ionization reactions and hydrolysis reactions to determine the nature of a salt. So the students could not determine what the proper formula to determine $\mathrm{pH}$ of a salt solution.

Based on the description above, efforts need to be developed and made to analyze students' mental models in explaining salt hydrolysis topic to make learning becomes effective and efficient. The purpose of this study was to analyze the mental models of students at SMAN 8 Jakarta on salt hydrolysis topic.

\section{RESEARCH METHOD}

The Qualitative analysis of mental models was conducted in class XI students of SMAN 8 Jakarta on salt hydrolysis topic in the 2018/2019 academic year semester in February 2019.

In this study students who had studied hydrolysis topic were examined for the mental profile of the model, the design in this study described in detail the profiles of students' mental models through reasoned multiple choice instruments on salt hydrolysis topic especially salt derived from strong and basic acids, salts derived from acid weak and strong bases and salts derived from weak acids and weak bases based on the evaluation of the POE model. Then the students' answers were grouped according to Sendur et. All, Suja and Nurlita (2016) as described in the literature, and it was grouped into 4 types of mental models, namely: No Response / NR, (Specific Misconceptions / SM), Partially Correct / PC, Scientifically Correct / SC. Then each percentage of the mental model group was calculated based on the percentage interpretation category. Study consisted of steps, seen in Figure 1 (Fazio et al., 2017). 
study the literature on the characteristics of chemistry and mental models determine the subject matter, analysis of content, and analysis of the standards of competency and basic competencies of the 13 revisions.

develop diagnostic test mental models based on POE, LKS, and make transcripts of interviews related to salt hydrolysis material.

develop indicators of salt hydrolysis material.
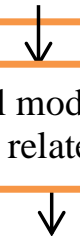

validate mental model diagnostic tests, as well as interview

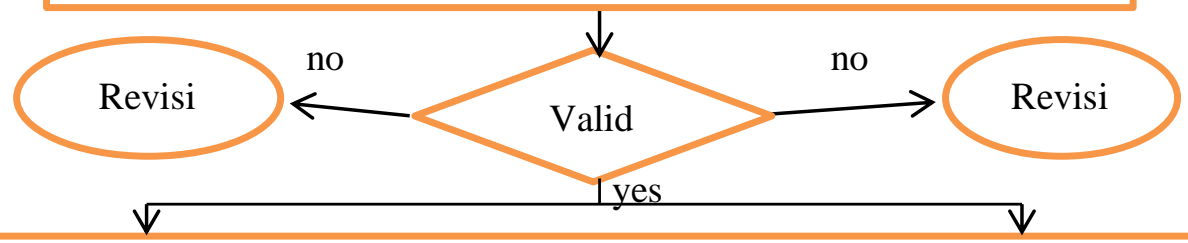

Conduct a research trial on salt hydrolysis material with the POE learning model at SMAN 8

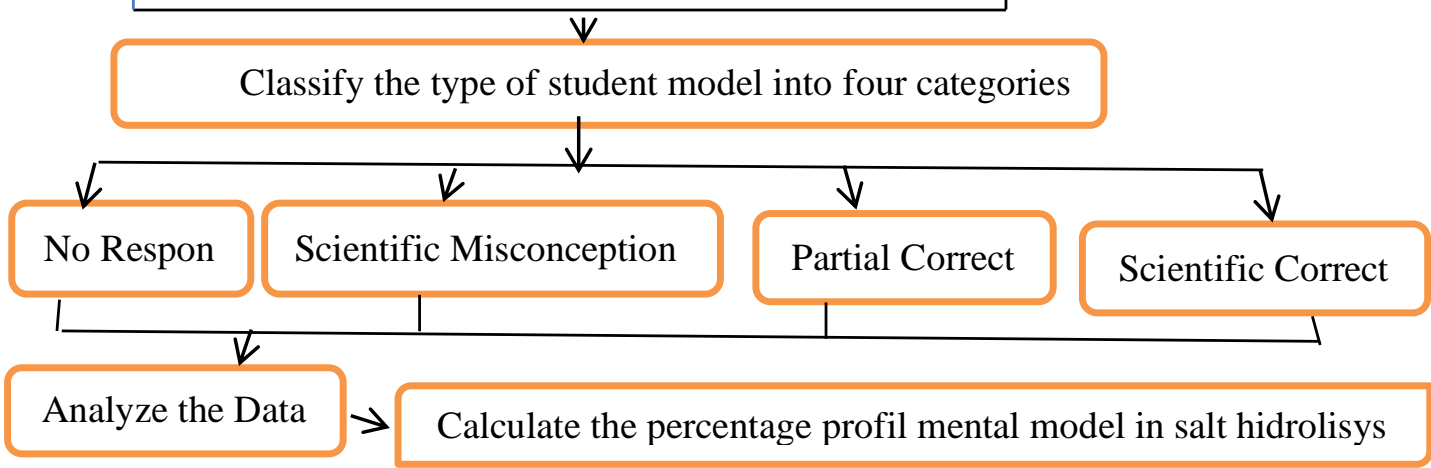

Figure 1. The Research Procedure

\subsection{Data Collection Techniques}

Data collection techniques were diagnostic test mental models, observations, interviews, and reflective journals. Data retrieval was done intensively in class XI IPA SMAN 8 Jakarta from February 2019 to March 2019. Data collection in this research was taken by certain methods or techniques as follows:
2.1.1. Test The Diagnostic Mental Model, Given At The Last Moment After Completion of Learning

Indicator for instrument : Several indicators of salt hydrolysis topic were formed, after studying this topic students were expected to be able : i.) Explain the meaning of salt hydrolysis objectively;.ii). Describe the nature of carefully hydrolyzed salts; iii). Describe the type of salt that is carefully hydrolyzed; iv). group salts undergoing total hydrolysis, partial hydrolysis is not hydrolyzed based on 
Analysis of Students Mental Models Through POE (Predict Observe Explain) Method in Salt Hydrolisis Topic

objective and precise acids and bases; v). Write down the ionization reaction from carefully hydrolyzed salt; vi). Determine the price of hydrolysis constants and the price of $\mathrm{pH}$ of carefully and responsibly hydrolyzed salts; vii). Analyze graphs of strong acid titrations and strong bases, strong acids and weak bases, weak acids and strong bases to explain buffer and hydrolysis solutions in a responsible and curiosity manner; viii). Mention the usefulness of hydrolysis in everyday life with an objective open fan.

\subsubsection{Observation}

Observation is a step in collecting field data to observe the behavior and activities of individuals at the research site. The researchers observed student behavior in learning and outside learning. In this step the researchers recorded the learning activities in and outside the classroom to find out information regarding the characteristics of students of XI IPA SMAN 8 Jakarta.

\subsubsection{Interview}

Interviews were used to establish communication with teachers and students in order to obtain an explanation of the learning of chemistry and mental models of students in class XI IPA SMAN 8 Jakarta. The interview technique that was conducted in this study was a semi-structured interview. According to Sugiyono [18], this type of interview is included in the category of in-depth interviews, where in its implementation it is freer and deeper than structured interviews.

\subsection{Data Analysis Technique}

Data analysis was started by analyzing the diagnostic test answers to mental models, namely by classifying the types of student models into four categories of student mental models No Response / NR, Specific Misconceptions / SM, Partially Correct / PC, Scientifically Correct / SC, besides classifying five types of mental models that is, the mental model has no response, mental models of misconception, partial mental models, consensus mental models and target models. Data analysis was continued by examining all available data from various sources; interviews, observations written in field notes, pictures, photographs, reflective student journals etc. After reading, studying, and reviewing, the next step is making data reduction by making a core summary during the data retrieval process. The process of data reduction was done by selecting research data needed to then be processed and analyzed. The next step was coding. This stage was done by compiling data in certain categories. The final stage of data analysis was the interpretation and analysis of data that had been obtained and made into certain codes [9]. The following were the stages of data analysis in the research that had been carried out: analyzing the answers to the mental model diagnostic test, doing data reduction, displaying data, drawing conclusions and verification.

\subsection{Quality Standards}

Results obtained in a study require the validity and accuracy of the data, this can be known by the quality standards used in a study. Quality standard used in this study was trustworthiness. Trustworthiness is the same criteria as valid, reliable, and objective in quantitative research (Guba and Lincoln, 1989). According to Guba and Lincoln (1989), this can be done through credibility. Criteria for credibility are parallel with internal validity in quantitative research. Between the findings and facts that exist can be replaced with the results obtained from the reality built from the respondent and the reconstruction of the cause. The degree of credibility is a criterion regarding the level of trust in the data. Data credibility is obtained by prolonged engagement (extension of participation), persistent observation (deep observation), 

Hydrolisis Topic

progressive subjectivity (monitoring of researchers in building their thoughts), and member checking (peer checking).

\section{RESULT AND DISCUSSION}

\subsection{Description of The Learning Process.}

The number of students in one class at SMAN 8 Jakarta are not more than 36 students per class. It is intended that the learning process can be taken place effectively and comfortably. The curriculum that is used used at SMAN 8 Jakarta is the 2013 curriculum. Learning is still done teacher-centered by using the lecture method, giving examples of questions then training. This was seen during the learning process and also stated by the chemistry teacher in the interview, as follows:

SMAN 8 Jakarta has implemented the 2013 curriculum since the 2014/2015 school year. However, learning has not fully referred to the student center. This is due to conditions in the learning time field that have not fully supported the implementation. there are a lot of technical things in the field that make many schedules of learning activities disrupted due to other activities such as try outs, school exams, and the National Examination (UN) which causes the teacher to keep completing the topic with shorter time with more dense topic at each meeting. (Chemistry teacher in Class XI of SMAN 8 Jakarta, interviewed on February 18, 2019).

In the study of salt hydrolysis topic the researcher gave a learning treatment using the POE (Predict Observe Explain) method. Prediction stages, researchers provided student worksheets (LKS) for students to predict the properties of salts. Students looked for literature to be able to predict the nature of these salts. Observation stages, the student prediction results from several salts were then tested with red litmus paper and blue litmus paper as well as $\mathrm{pH}$ indicators, students matched the predicted results with observing results from the experiments conducted. Explanation stages, students explain the results of observation with predict based on the literature and observations made in the experiment. This stage stimulates students to be open and dare to express opinions.

\subsection{Mental Model Students in Salt Hydrolysis Topic}

Mental models of students in salt hydrolysis topic were known through in-depth interviews with students regarding the concept of salt hydrolysis and salt hydrolysis process. Based on the results of the interview, some students were able to explain the hydrolysis of salt well, such as: Hydrolysis is the reaction of cations / anions from salt with water. Cations that can undergo hydrolysis are conjugate acids from weak bases and anions which can undergo hydrolysis is the conjugate base of a weak acid (Student 01, interviewed on March 4, 2019).

The student's answer was in accordance with the understanding of hydrolysis according to reference, which states that hydrolysis is a reaction of anions or cations or both of them from a salt with water (Chang, 2005) However, not all anions and cations from salt can react hydrolysis with water. Only cations are conjugate acids from weak bases and anions which are conjugate bases of weak acids that can be hydrolyzed in water. Student 01 correctly answered hydrolysis based on the understanding and knowledge that he found out in various references. Students build mental models by constructing, it means that students see something that is not in their thinking, then with the POE learning process, students built a mental model of the knowledge gained by students. The concept of the hydrolysis reaction process is a concept that requires understanding at the macroscopic, submicroscopic, and symbolic 
Analysis of Students Mental Models Through POE (Predict Observe Explain) Method in Salt Hydrolisis Topic

level. The $\mathrm{pH}$ value of hydrolyzed salt solutions that can be measured using universal $\mathrm{pH}$ paper is an example of macroscopic representation, the hydrolysis reaction process in the form of decomposition of salts into ions in water is a microscopic representation, and the reaction equation and $\mathrm{pH}$ calculation of hydrolyzed salt solutions are symbolic representations. Students wrote the hydrolysis reaction equation as follows: (seen figure 2 ).

Figure 2. Equation of Hydrolysis Reaction Made by Students 01

The student's answer showed that a mental model that is in accordance with the concept of the hydrolysis process. Students' answers were in accordance with the stages of hydrolysis found in the literature, which states that the hydrolysis process of salt occurs when salts dissolved in water decompose from the form of salt which is a neutral compound into ions in the form of anions and cations. Cations which are conjugate acids from weak bases and / or anions which are conjugate bases of weak acids then react with water molecules $\left(\mathrm{H}_{2} \mathrm{O}\right)$ to form an acid-base equilibrium system (Chang, 2005; Treagust, 2016). The mental model that fits this concept was obtained by students because students read books and studied them. Students mentioned that the process of decomposing salts into ions as an ionization process.

Some students have mental models of alternative concepts built by the students themselves, namely: Hydrolysis is a reaction between salts which are initially neutral and then dissolved in water and become ions. All of these ions then react with water to produce $\mathrm{H+}$ or $\mathrm{OH}$ - (Student 02, interviewed on February 4, 2019).

The student's answer showed that students generalize about hydrolysis ions. Students understand that all ions produced when salt is dissolved in water can be hydrolyzed to form $\mathrm{H}^{+}$and $\mathrm{OH}^{-}$. The students answers were formed by students based on students' understanding without being accompanied by sufficient literature so that alternative concepts arise regarding the notion of hydrolysis. In addition, there were other alternative concepts that students have, namely: Hydrolysis is a decomposition reaction of salt compounds by water (Student 03, interviewed on March 4, 2019).

Student answer 03 was formed because of a language understanding of hydrolysis derived from the word hydro which means water and lysis it means decomposition or division. This student's understanding was formed from the teacher's explanation when explaining the meaning of the word hydrolysis during the initial meeting of hydrolysis topic. Students built understanding based on their experiences when first given an explanation by the teacher about hydrolysis. According to students, such understanding was easier to understand so students form the concept of hydrolysis based on what students think is easy to understand.

Hydrolysis is an acid-base reaction with $\mathrm{H}_{2} \mathrm{O}$ molecules (Student 04, interviewed on March 4, 2019)

Students' answers showed an alternative concept that is not appropriate, where students assumed that hydrolysis is an acidbase reaction with water molecules. It happened because students did not have a 
good understanding of hydrolysis so students built mental models of hydrolysis. Students with answers like this wrote the hydrolysis reaction equation as follows: (seen figure 3 ).

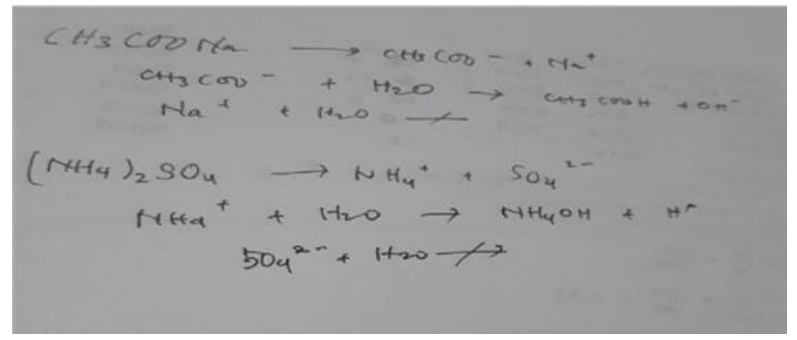

Figure 3. Equation of Hydrolysis Reaction Made by Students 04

This student's answer showed an alternative concept mental model that students have. Based on the literature, the reaction between hydrolyzed anions and cations forms acidbase equilibrium. However, students who have mental models with alternative concepts such as the answer above write that hydrolysis reactions occur in one direction.
Analysis of Students Mental Models Through POE (Predict Observe Explain) Method in Salt Hydrolisis Topic

Diagnostic test mental model was made in the form of 10 reasoned multiple choice questions. Student answers were analyzed and grouped into 4 types of mental models, namely: if the correct answer was correct, students entered the Scientific Correct / SC category, if the student's answer was correct and the reason was wrong or vice versa then the student falls into the Partially Correct / PC category if the student's answer was wrong and the reason was wrong so the student is included in the category Misconception Specific / MS, if the student did not answer and did not give the answer entered in the No Response / NR category. The results showed that $3.88 \%$ of respondents had a Specific Misconceptions / SM mental model, 7.9\% Partially Correct / PC and 88.146\% Scientifically Correct / SC. It can be concluded that the respondents almost all have Scientifically Correct mental models and show themes that appear at each macroscopic, symbolic and macroscopic ( seen Table 1).

Table 1. Percentage of Mental Model Type with Respondents 36 Students

\begin{tabular}{|c|c|c|c|}
\hline $\begin{array}{c}\text { Number } \\
\text { test }\end{array}$ & SC & PC & MS \\
\hline 1 & 83.33\% (30 students) & $13.88 \%$ (5 students) & 2.77\% (1 students) \\
\hline 2 & $80.55 \%$ (29 students) & $16.66 \%$ (6 students) & $2.77 \%$ (1 students) \\
\hline 3 & $86,11 \%$ (31 students) & $11.11 \%$ (4 students) & $2.77 \%$ (1 students) \\
\hline 4 & $100 \% \quad$ (36 students) & - & - \\
\hline 5 & 83.33\% (30 students) & $2.77 \%$ ( 1 students) & $13.8 \%$ (5 students) \\
\hline 6 & $100 \% \quad$ (36 students) & - & - \\
\hline 7 & $100 \% \quad$ (36 students) & - & - \\
\hline 8 & $100 \% \quad$ (36 students) & - & - \\
\hline 9 & $100 \% \quad$ (36 students) & - & - \\
\hline 10 & $100 \% \quad$ (36 students) & - & - \\
\hline 11 & $100 \% \quad$ (36 students) & - & - \\
\hline 12 & $100 \% \quad$ (36 students) & - & - \\
\hline 13 & $61,11 \%$ (22 students) & $25 \%$ (9 students) & $13.88 \%$ (5 students) \\
\hline 14 & $100 \% \quad$ (36 students) & - & - \\
\hline 15 & $63,88 \%$ (23 students) & 27.7\% (10 students) & 8.33\% ( 3 students) \\
\hline Mean & $88,146 \%$ & $7.96 \%$ & $3.88 \%$ \\
\hline
\end{tabular}


The table shows the mental model of 36 respondents, the highest in the Scientific Correct model type of $88.146 \%$, specific misconceptions $3.88 \%$ and specific misconceptions $7.96 \%$.

\section{ACKNOWLEDGEMENT}

Thank you to Mr. Afrizal as a supervisor who has helped for succes of this research.

\section{CONCLUSION}

Students at SMAN 8 Jakarta constructed mental models by constructing, it means that students saw something that does not exist in their thinking, then with the POE learning process, students constructed a mental model of the knowledge gained by students. The concept of the hydrolysis reaction process is a concept that requires understanding at the macroscopic, submicroscopic, and symbolic level. The $\mathrm{pH}$ value of hydrolyzed salt solutions that can be measured using universal $\mathrm{pH}$ paper is an example of macroscopic representation, the hydrolysis reaction process in the form of decomposition of salts into ions in water is a microscopic representation, and the reaction equation and $\mathrm{pH}$ calculation of hydrolyzed salt solutions are symbolic representations.

The results diagnostic test mental model at SMAN 8 Jakarta showed that $3.88 \%$ of respondents had a Specific Misconceptions / SM mental model, 7.9\% Partially Correct / PC and $88.146 \%$ Scientifically Correct / SC. It can be concluded that the respondents almost all have Scientifically Correct mental models and show themes that appear at each macroscopic, symbolic and microscopic. 
Analysis of Students Mental Models Through POE (Predict Observe Explain) Method in Salt Hydrolisis Topic

\section{REFERENCES}

Buckley, B. C., \& Boulter, C. J. (2000). Investigating The Role of Representations and Expressed Models in Building Mental Models. Developing Models in Science Education, 119-135. Springer, Dordrecht.

Chang, R. (2005). Kimia Dasar Konsep-Konsep Inti. Jakarta: Erlangga.

Chermack, T. J., Song, J. H., Nimon, K., Choi, M., \& Korte, R. F. (2012). The Development and Assessment of An Instrument for Measuring Mental Model Styles in Korea. Learning and Performance Quarterly, 1(1), 1-20.

Darmiyanti, W., Rahmawati, Y., Kurniadewi, F., \& Ridwan, A. (2017). Analisis Model Mental Siswa dalam Penerapan Model Pembelajaran Learning Cycle 8E pada Materi Hidrolisis Garam. JRPK: Jurnal Riset Pendidikan Kimia, 7(1), 38-51.

Fazio, C., Battaglia, O. R., \& Sperandeo-Mineo, R. M. (2017). Quantitative and Qualitative Analysis of The Mental Models Deployed by Undergraduate Students in Explaining Thermally Activated Phenomena. Scientia in educatione, 8.

Guba, E. G., \& Lincoln, Y. S. (1989). Fourth generation evaluation. Newbury Park: Sage Publication.

Halim, N. D. A, Ali, M. B., Yahaya, N., \& Said, M. N. H. M. (2013). Mental Model in Learning Chemical Bonding: A Preliminary Study. Procedia-Social and Behavioral Sciences, 97, 224-228.

Harrison, A. G., \& Treagust, D. F. (2000). Learning about Atoms, Molecules, and Chemical Bonds: A Case Study of
Multiple-model use in Grade 11 Chemistry. Science Education, 84(3), 352381.

Johnstone, A. H. (1991). Why is Science Difficult to Learn? Things are Seldom what They Seem. Journal of Computer Assisted Learning, 7(2), 75-83.

Johnstone, A. H. (1993). The Development of Chemistry Teaching: A Changing Response to Shanging Demand. Journal of Chemical Education, 70(9), 701.

Murezhawati, E., Hairida \& Melati, H.A. (2016). Peningkatan Keterampilan Proses Sains Siswa SMA dengan Model Pembelajaran Predict-Observe-Explain Materi Hidrolisis Garam. Jurnal Pendidikan dan Pembelajaran Khatulistiwa, 6(8).

Park, E. J., \& Light, G. (2009). Identifying Atomic Structure as A Threshold Concept: Student Mental Models and Troublesomeness. International Journal of Science Education, 37(2), 233-258.

Sari, R. P., \& Seprianto, S. (2018). Analisis Kemampuan Multipel Representasi Mahasiswa FKIP Kimia Universitas Samudra Semester II pada Materi Asam Basa dan Titrasi Asam Basa. Jurnal Pendidikan Sains Indonesia (Indonesian Journal of Science Education), 6(1), 55-62.

Sugiyono (2012). Metode Penelitian Pendidikan. Bandung: Alfabeta.

Suja, I. W., \& Nurlita, F. (2016). Persepsi dan Model Mental Mahasiswa Tahun Pertama Terhadap Pembelajaran Kimia Organik di SMA. In Seminar Nasional Riset Inovatif, 4.

Treagust, D. F., \& Chandrasegaran, A. L. (2007). The Taiwan National Science Concept Jurnal Tadris Kimiya 5, 1 (Juni 2020): 80-90 

Hydrolisis Topic

Learning Study in An International Perspective. International Journal of Science Education, 29(4), 391-403.

Treagust, D.F. (2016). Sources Of Student Difficulties In Learning Chemistry.

White, R. T., \& Gunstone, R. F. (1992). Probing understanding. New York: The Falmer Press. 